\title{
Behaviour of dissolved organic matter during formation of natural and artificially grown Baltic Sea ice
}

\author{
Susann MÜLLER, ${ }^{1}$ Anssi V. VÄHÄTALO, ${ }^{1,4}$ Mats A. GRANSKOG, ${ }^{2}$ Riitta AUTIO, ${ }^{3}$ \\ Hermanni KAARTOKALLIO ${ }^{3}$ \\ ${ }^{1}$ Department of Environmental Sciences, University of Helsinki, PO Box 65, FIN-00014 Helsinki, Finland \\ E-mail: susann.mueller@helsinki.fi \\ ${ }^{2}$ Norwegian Polar Institute, Polar Environmental Centre, NO-9296 Tromsø, Norway \\ ${ }^{3}$ Marine Research Centre, Finnish Environment Institute, PO Box 140, FIN-00251 Helsinki, Finland \\ ${ }^{4}$ ARONIA Coastal Zone Research Team, Åbo Akademi University and Novia University of Applied Sciences, Ekenäs, Finland
}

\begin{abstract}
During sea-ice formation, the dissolved constituents of water are rejected from ice crystals. The initial fractionation of dissolved organic matter (DOM) in the Baltic Sea ice was studied through two freezing experiments and by sampling natural sea ice. DOM was characterized by the spectral absorption of chromophoric DOM (CDOM) and the parallel factor analysis of DOM fluorescence. Molecular weight measurements of DOM were applied to assess changes in the molecular size distribution of DOM in new sea ice relative to parent sea water. Both in the newly formed artificial and the natural sea ice, CDOM was enriched by $34-39 \%$ relative to salinity. The same three identified DOM fluorophores were present both in sea water and ice but enriched by $15-54 \%$ relative to salinity in ice. After the incorporation of DOM into ice, the ageing of ice decreased the spectral slope coefficient and the molecular weight of DOM. This study shows that physical processes during freezing of brackish water enrich chromo- and fluorophoric DOM relative to salts in sea ice.
\end{abstract}

\section{INTRODUCTION}

Dissolved organic matter (DOM) is a complex mixture of uncharacterized organic molecules including high molecular humic or fulvic acids (Benner and others, 1992). DOM is generated by biological activity and it contributes to the global carbon cycle, because it serves as a substrate for the microbial food web and will be mineralized to $\mathrm{CO}_{2}$ (Benner and others, 1992; Amon and Benner, 1996; Giannelli and others, 2001; Vähätalo, 2009). The main DOM-degrading processes are microbial and photochemical decomposition, which supply nutrients for autotrophic organisms (Vähätalo and Wetzel, 2004; Vähätalo, 2009).

In sea ice, DOM is an important factor controlling the biological processes and the optical properties within and underneath the ice (Thomas and others, 1995, 2008). Sea-ice DOM can originate from parent water (Giannelli and others, 2001; Stedmon and others, 2007a), but it can also be autochthonously produced within brine channels or released by mechanical stress on cells (Thomas and others, 2001). In the Baltic Sea, the humic substances from sea water dominate the fluorescence of sea-ice DOM, but a prominent protein-like fluorescence indicates also the autochthonous production of DOM in ice (Stedmon and others, 2007a). Because DOM absorbs radiation in the visible, UV-A and UV-B wavelength ranges, the composition and concentration of optically active chromophoric DOM (CDOM) affects the quality and quantity of light in sea ice and under-ice water (Uusikivi and others, 2010). The optical characteristics of DOM entrapped in sea ice affect the productivity of autotrophic organisms (Belzile and others, 2000).

Giannelli and others (2001) observed an enrichment of dissolved organic carbon (DOC) relative to salts in sea ice grown from artificial sea water. A similar enrichment of DOC relative to salts has been observed in the brackish Baltic Sea ice, where the major inorganic ions also are excluded differently during freezing (Granskog and others, 2004).
DOM is enriched relative to salts also in the ice of saline lakes (Belzile and others, 2002). In freshwater ice, the exclusion of DOM is more extensive than in ice formed from saline water, and DOM can be depleted more than salts (Belzile and others, 2002). It is also known that the magnitude of DOM exclusion depends on the growth velocity of ice (Belzile and others, 2002). However, little is known about the parameters controlling DOM fluxes between ice and under-ice water during the initial freezing of sea water. It is still unknown, whether the freezing process itself, the fractionation during the ice formation or the condition within the sea ice during ageing affects the quantity or quality of DOM.

This study examined the changes in the quality and quantity of DOM during ice formation in brackish waters under natural and controlled (laboratory) conditions. We related the behaviour of CDOM and fluorophoric DOM (FDOM) to that of inorganic salts quantified as salinity. This salinity-normalized approach allowed us to take into account the difference in physical conditions such as temperature during the ice formation. A variation in temperature causes a large change in brine expulsion and gravity drainage (Niedrauer and Martin, 1979). By selecting the salinitynormalized approach in this study, we were able to compare the behaviour of DOM to the conservative salinity exclusion used as a tracer for purely physical brine exclusion (Granskog and others, 2005). We also assessed changes in the molecular size distribution of DOM by liquid chromatography-size exclusion chromatography (LC-SEC) and the spectral slope coefficient of CDOM to specify the alteration of DOM during the formation and the ageing of sea ice.

\section{MATERIAL AND METHODS}

Study area

The brackish Baltic Sea with its low salinities of 1-9 has a large catchment area. Unlike the open oceans, the Baltic Sea 
derives a large proportion of the DOM from terrestrial sources and is therefore characterized by high concentrations of CDOM (Stedmon and others, 2000). Seasonal sea ice forms regularly every winter in the Baltic Sea (Vihma and Haapala, 2009). At salinities higher than 1, Baltic Sea ice includes brine pockets and channels like its polar counterpart (Kawamura and others, 2001). The porosity of the Baltic Sea is low compared to that of polar sea ice (Meiners and others, 2002). The Baltic Sea ice is rich in CDOM, so its optical properties differ from those of polar sea ice (Ehn and others, 2004; Uusikivi and others, 2010).

\section{Experimental design}

In this study, we carried out two freezing experiments in a laboratory in 2007 and 2008 (referred to as exp07 and exp08, respectively). Additionally, we examined natural Baltic Sea ice in 2007 and 2008 (referred to as nat07 and nat08, respectively).

\section{Freezing experiment 2007 (exp07)}

Sea water was collected from $2 \mathrm{~m}$ depth with a Limnos water sampler at the archipelago near Tvärminne Zoological Station (University of Helsinki), located in the northwestern part of the Gulf of Finland. Polyethylene (PE) buckets (washed with deionized water) were filled with $1.5 \mathrm{~L}$ of sea water and kept at -17 to $-20^{\circ} \mathrm{C}$. After 2 hours, a thin layer of ice formed on the top of the water and on the walls of the buckets. The liquid water was collected into an Erlenmeyer flask by drilling a hole through the formed ice with a battery-operated drill and pre-cleaned drill-bit. The ice was allowed to melt at $5^{\circ} \mathrm{C}$ overnight and then filtered along with the water samples through GF/F (glass-fiber $F$ grade; Whatman, nominal pore size $0.7 \mu \mathrm{m}$ ) into a precombusted all-glass filtration device applying low vacuum. Absorption spectra of CDOM and salinity from these samples were analyzed within 2 days.

\section{Tank experiment 2008 (exp08)}

The behaviour of DOM during ice growth was studied during a 144 hour long freezing experiment at the Finnish Institute of Marine Research. Surface water from $\sim 5 \mathrm{~m}$ depth from the central Gulf of Finland $\left(24^{\circ} 50^{\prime} \mathrm{N}, 59^{\circ} 51^{\prime} \mathrm{E}\right)$ was collected in the last week of January 2008 from R/V Aranda using a flow-through system, and stored at $4{ }^{\circ} \mathrm{C}$ in the dark for $\sim 2$ weeks. Four tanks were filled with $360 \mathrm{~L}$ of unfiltered sea water and circulated by a pump system $\left(150 \mathrm{~L} \mathrm{~h}^{-1}\right)$. For the purposes of other experiments reported elsewhere, a defined amount of organic carbon was added to each tank as follows: tank A: no addition; tank B: the lysate of coldwater diatom Achnantes taeniata to a final concentration of $16 \mu \mathrm{g} \mathrm{C}^{-1}$; tank $\mathrm{C}$ : the lysate of cold-water dinoflagellate Scrippsiella hangoei to a final concentration of $100 \mu \mathrm{g} \mathrm{CL}^{-1}$; and tank D: sucrose to a final concentration of $400 \mu \mathrm{g} \mathrm{CL}^{-1}$. $\mathrm{NO}_{3}$ concentration was adjusted to the ambient level of tank $\mathrm{C}\left(13 \mu \mathrm{mol} \mathrm{L}^{-1}\right)$ by addition of nitrate to tanks A, B and D. Despite the additions of carbon, there was no significant difference in CDOM, FDOM or the molecular mass of DOM among the tanks (data not shown). Therefore the tanks are treated as replicates in this study.

Sea ice was grown at $-5^{\circ} \mathrm{C}$ in tanks with isolated heated walls, which allowed ice formation only at the surface of the tanks. The tanks were irradiated with fluorescent tubes emitting $80-100 \mu \mathrm{mol}$ photons $\mathrm{m}^{-2} \mathrm{~s}^{-1}$ at a spectral range of $400-700 \mathrm{~nm}$ to the surface of tanks for 6 hours $^{-1}$, simulating a day length in February in the northern Baltic Sea. Ice samples were collected after 1 week of ice growth $(10-17.5 \mathrm{~cm}$ ice thickness) with a custom-made miniature stainless-steel ice corer $(7 \mathrm{~cm}$ internal diameter (id), Nordic Ice Drill, Sweden). The ice was allowed to melt at $+4{ }^{\circ} \mathrm{C}$ in acid-washed PE containers for 24 hours in the dark. Water samples were taken with a $1 \mathrm{~L}$ PE bin and stored in the dark in $1 \mathrm{~L}$ acid-washed glass bottles at $+4^{\circ} \mathrm{C}$ until subsampling into $100 \mathrm{~mL}$ pre-combusted glass bottles within 2 hours. All samples were filtered with $0.45 \mu \mathrm{m}$ syringe filters (cellulose acetate, Whatman GD/X) into pre-combusted $\left(450^{\circ} \mathrm{C}\right.$ for 3 hours) glass vials. The samples were stored in the dark at $+4^{\circ} \mathrm{C}$ for $1-3$ weeks until further analysis. For LC-SEC analysis, samples were fixed with mercury(II)-chloride $\left(50 \mathrm{mg} \mathrm{L}^{-1}\right)$ and measured 18 months after sampling.

\section{Natural ice 2008 (nat08)}

In addition to tank experiments, natural ice was investigated in this study. New ice was collected near Tvärminne Zoological Station on 13 February 2008. The ice had formed overnight during $<12$ hours to a layer $\sim 2 \mathrm{~cm}$ thick. Under-ice water was sampled directly into acid-washed glass bottles rinsed several times with the sampled water. Pieces of ice were collected into cooling boxes cleaned with ultrapure water (Milli-Q) and melted at $4{ }^{\circ} \mathrm{C}$ in the dark. Ice and water samples were filtered $(0.45 \mu \mathrm{m}$ syringe filters; Pall Acrodisc, Supor membrane) into pre-combusted $\left(450^{\circ} \mathrm{C}\right.$ for 3 hours) glass vials and stored in the dark at $+4^{\circ} \mathrm{C}$ for $1-3$ weeks before CDOM and FDOM were measured. Samples for LC-SEC analysis were fixed with mercury(II)-chloride with a final concentration of $50 \mathrm{mg} \mathrm{L}^{-1}$ and measured 18 months after sampling.

\section{Natural ice 2007 (nat07)}

Naturally grown ice was sampled on 12 March 2007, from the same location as the young natural ice. The ice was approximately 5 weeks old and $22 \mathrm{~cm}$ thick. Ice coring was done using an ice auger $(9 \mathrm{~cm}$ id; Kovacs Enterprises, Lebanon $\mathrm{NH}, \mathrm{USA}$ ). The ice core was cut into three layers and each was kept in pre-cleaned PE buckets in the dark at room temperature to melt overnight. Under-ice water was sampled from the same location, but on 14 March 2007 from $2 \mathrm{~m}$ depth using a Limnos water sampler (Limnos, Finland). Ice and water samples were filtered after melting through GF/F (Whatman, nominal pore size $0.7 \mu \mathrm{m}$ ) and collected in a pre-combusted all-glass filtration device applying low vacuum. CDOM and salinity measurements were carried out within 2 days.

\section{Analytical methods}

\section{Field measurements}

Salinities of water and melted ice samples of the tank experiment (exp08) and natural samples (nat08) were measured using a YSI 63 hand-held S/T meter (Yellow Springs Instruments, Yellow Springs, OH, USA) whereas nat07 and exp07 were measured with a Radiometer CDM 83 and reported as practical salinity units. Salinities prior to LC-SEC analysis of the samples from exp08 and nat08 were adjusted with ultrapure water (Milli-Q) to a salinity of 1 and measured with a VWR EC300 conductivity meter.

\section{CDOM absorption}

CDOM absorption spectra for all samples were measured using a Shimadzu UV-2101 spectrophotometer in a $10 \mathrm{~cm}$ 
quartz cell over the $200-800 \mathrm{~nm}$ range in $1 \mathrm{~nm}$ increments and with $2 \mathrm{~nm}$ slit width. The samples were allowed to warm up to room temperature in the dark before measurement. Three replicates of each sample were measured and corrected with an ultrapure water (Milli-Q) blank at room temperature.

The absorption coefficient, $a$, at wavelength $\lambda$ was calculated using

$$
a_{\lambda}=2.303 A_{\lambda} 0.1^{-1}
$$

where $A_{\lambda}$ is the mean absorbance at wavelength $\lambda$.

\section{Spectral slope}

Spectral slope coefficient of the CDOM absorption between 300 and $400 \mathrm{~nm}$ (Slope $300-400$ ) was calculated by a nonlinear regression (Stedmon and Markager, 2003) using the 'Curve Fitting Tool' of MATLAB (version R2007b, Mathworks, US) and the following equation:

$$
a_{\lambda}=a_{300} \exp \left[\operatorname{Slope}_{300-400}(300-\lambda)\right] .
$$

The range of the spectral slope was chosen to ensure reliable quantitative CDOM signals with an absorbance of $<1$ and more than three times the standard deviation between replicates (Twardowski and others, 2004). The spectral slope coefficient of exp08 represents the median value of all four tanks.

\section{Fluorescence of DOM}

Fluorescence intensities of samples from 2008 were measured in a $1 \mathrm{~cm}$ quartz cell with a Varian Cary Eclipse spectrofluorometer over an excitation range of 240-450 nm in $2 \mathrm{~nm}$ increments while scanning the emission from 300 to $600 \mathrm{~nm}$ in $5 \mathrm{~nm}$ increments. The slit widths for excitation and emission scans were $5 \mathrm{~nm}$. Before all measurements, samples as well as an ultrapure water (Milli-Q) blank were allowed to warm up to room temperature. Instrumental excitation and emission corrections were derived from excitation spectra of concentrated Rhodamine B solution $\left(3 \mathrm{~g} \mathrm{~L}^{-1}\right.$ Rhodamine $\mathrm{B}$ in ethylene glycol) and an emission spectrum resulting from a ground quartz diffuser (Stedmon and others, 2007b). An inner filter correction was done as suggested by Mobed and others (1996), Lakowicz (1999) and Ohno (2002), and the fluorescence intensity was normalized to the area under the Raman scatter peak of ultrapure water at the excitation wavelength of $350 \mathrm{~nm}$. The excitation emission matrices (EEMs) were also corrected for the Rayleigh scatter by setting the area under the Rayleigh peak to zero (see Stedmon and others, 2007b; Stedmon and Bro, 2008).

DOM fluorophores were identified and quantified by parallel factor analysis (PARAFAC) using the $\mathrm{N}$-way toolbox of MATLAB (Stedmon and others, 2003; Stedmon and Bro, 2008). From the 14 samples measured, the number of fluorophores was determined by a split-half validation and a residual analysis (Stedmon and Bro, 2008). The mean maximal fluorescence signals (Fmax) were used for the quantification of fluorophores.

\section{Enrichment factor $D_{C}$}

For each sample, the CDOM absorption coefficient at $350 \mathrm{~nm}$ and the maximal fluorescence intensities of each fluorophore (Fmax), both described here by $C$, were normalized to the corresponding salinity $(c / S)$. Then the enrichment factor, $D_{c}$, for DOM was calculated as

$$
D_{c}=\frac{\left(\frac{c}{S}\right)_{\mathrm{i}}-\left(\frac{c}{S}\right)_{\mathrm{w}}}{\left(\frac{c}{S}\right)_{\mathrm{w}}},
$$

where subscripts i and w refer to ice and water, respectively (modified after Weeks and Ackley, 1982). In Equation (3), the identical behaviour of DOM and salinity results in an enrichment factor of 0 .

For $D_{c}$ of natural samples of nat08, ice samples were related to the under-ice water samples on the sampling day. No $D_{c}$ value is calculated for nat07, because of missing salinity values in the under-ice water. For the calculation of $D_{c}$ of experimentally grown ice, the $(c / S)_{\mathrm{w}}$ ratio refers to the 'initial water'.

\section{Molecular-weight distribution}

LC-SEC was performed using a silica-based TSK G3000SWxI column $(7.8 \mathrm{~mm} \times 30 \mathrm{~cm}$, pore size $=250 \AA, 5 \mu \mathrm{m}$ particle size) and a TSK guard column $(7.5 \mathrm{~mm} \times 7.5 \mathrm{~mm})$ with a Hewlett Packard 1100 series high-performance liquid chromatography (HPLC) instrumentation using ultraviolet (UV) detection at $254 \mathrm{~nm}$. A phosphate buffer $\left(3.58 \mathrm{~g} \mathrm{~L}^{-1}\right.$ $\mathrm{Na}_{2} \mathrm{HPO}_{4}$ and $1.36 \mathrm{~g} \mathrm{~L}^{-1} \mathrm{KH}_{2} \mathrm{PO}_{4}$, ionic strength $20 \mathrm{mM}$ ) at $\mathrm{pH} 6.85$ was used as eluent at a flow rate of $0.8 \mathrm{~mL} \mathrm{~min}^{-1}$, and a sample $(100 \mu \mathrm{L})$ was injected to the column at $20^{\circ} \mathrm{C}$ (Allpike and others, 2005). The retention times of samples were compared to other DOM mixtures or compounds with a known molecular weight. The Nordic fulvic acid reference with the mean molecular weight $M_{w}=2138 \mathrm{~g} \mathrm{~mol}^{-1}$ was used as a reference at a concentration of $9 \mathrm{mg} \mathrm{L}^{-1}$ (International Humic Substances Society; Hongve and others, 1996). Blue Dextran 2000 (Sigma; $100 \mathrm{mg} \mathrm{L}^{-1}$; $2 \times 10^{6} \mathrm{~g} \mathrm{~mol}^{-1}$ ) was used as a marker for the high molecular mass fraction, whereas tyrosine $\left(200 \mathrm{mg} \mathrm{L}^{-1} ; 181.2 \mathrm{~g} \mathrm{~mol}^{-1}\right)$ and phenylalanine $\left(100 \mathrm{mg} \mathrm{L}^{-1} ; 165.2 \mathrm{~g} \mathrm{~mol}^{-1}\right)$ indicated the low molecular mass range. A baseline correction was done for all samples by normalizing the chromatogram to the value at $12 \mathrm{~min}$. In this study, the retention time, $R_{\mathrm{t}}(\mathrm{min})$, between 12 and 20 min was used directly to describe the molecular size distribution of DOM. The mean retention time (corresponding to the weight-averaged molecular mass of DOM) was calculated as

$$
R_{\mathrm{t}}=\Sigma\left(h_{i} \times R_{\mathrm{t}, i}^{2}\right) / \Sigma\left(h_{i} \times R_{\mathrm{t}, i}\right),
$$

where $h_{i}$ is the absorbance at $254 \mathrm{~nm}$ at the retention time $R_{\mathrm{t}, i}$. In LC-SEC, molecules with large molecular mass have short retention times, and the retention time increases for molecules with decreasing molecular mass.

Prior to LC-SEC analysis, the salinities of under-ice water samples of exp08 and nat08 were adjusted with Milli-Q water to 1 , equivalent to the salinity found in the ice samples of exp08.

\section{RESULTS \\ Quantity of DOM}

\section{CDOM absorption}

In order to quantify the behaviour of DOM in Baltic Sea ice during initial freezing, a short-term experiment was carried out (exp07). The absorption coefficient of CDOM at $350 \mathrm{~nm}$ $\left(a_{\mathrm{CDOM}, 350}\right)$ after 2 hours of freezing was $4.3 \mathrm{~m}^{-1}$ and $1.9 \mathrm{~m}^{-1}$ in the under-ice water and in the melted ice, respectively, and $3.7 \mathrm{~m}^{-1}$ in the initial water sample (Fig. 1a; Table 1). The 

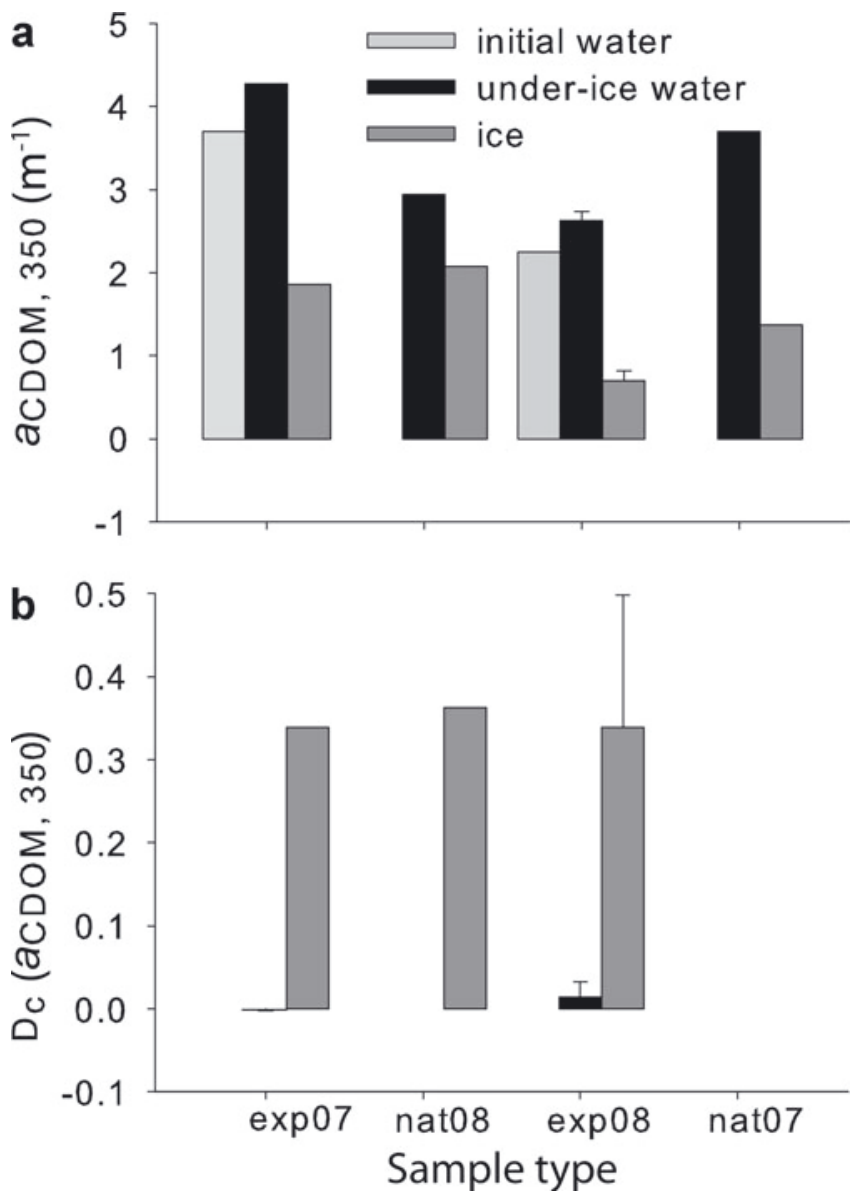

Fig. 1. Absorption coefficients at $350 \mathrm{~nm}$ of natural and experimentally grown sea ice (dark grey bars) and under-ice water (black bars) after 2-840 hours of ice growth. Error bars indicate the standard deviation between replicates (a). The enrichment factor $D_{c}$ (b) relates the salinity-normalized $a_{\mathrm{CDOM}, 350}$ to the pre-freezing conditions in the initial water (grey bars). decrease of $\mathrm{a}_{\mathrm{CDOM}, 350}$ by $51 \%$ in newly formed ice relative to the initial water sample shows that CDOM was partially rejected during ice formation. In the under-ice water, the concentration of $\mathrm{a}_{\mathrm{CDOM}}, 350$ was elevated by $16 \%$ in relation to the initial water. The enrichment factor $D_{C}$ (Equation (3)) was calculated to compare the fractionation of $a_{\mathrm{CDOM}, 350}$ against the behaviour of salinity. The $D_{C}$ value was 0.34 for ice, but 0 for under-ice water (Fig. $1 b$ ). These results show that $a_{\mathrm{CDOM}, 350}$ was enriched relative to salinity in ice, but in water, $a_{\mathrm{CDOM}, 350}$ behaved conservatively.

The behaviour of $\mathrm{a}_{\mathrm{CDOM}, 350}$ during initial freezing was also measured under natural conditions (nat08). After 12 hours of ice formation, the $a_{\mathrm{CDOM} / 350}$ of ice was again lower than in the under-ice water (Fig. 1a; Table 1). The $D_{c}$ value of ice relative to the under-ice water was even slightly higher than during the freezing experiment, again indicating enrichment relative to salinity (Fig. 1b; Table 1).

We also studied the behaviour of DOM during a longer period of ice growth (exp08). After 1 week of ice growth, the $a_{\mathrm{CDOM} / 350}$ of artificial sea ice was $30 \%$ of the value in the initial water sample, whereas a $13 \%$ increase was found in the under-ice water (Fig. 1a). Again, $D_{c}$ values showed that CDOM was enriched relative to salinity in ice, but not in under-ice water (Fig. 1b; Table 1). In a 5 week old naturally grown ice (nat07), $a_{\mathrm{CDOM}, 350}$ was $37 \%$ of that in the underice water (Fig. 1a; Table 1).

\section{Fluorescence of DOM}

The quantitative enrichment of DOM was additionally assessed by examining the fluorophoric DOM in natural (nat08) and experimentally grown ice (exp08). For these samples, the PARAFAC analysis identified three fluorophores. Fluorophore 1 (C1) had excitation maxima at 240 and $340 \mathrm{~nm}$, with the emission maximum at $484 \mathrm{~nm}$ (Fig. 2). Fluorophore 2 (C2) had excitation maxima at 240 and $305 \mathrm{~nm}$, with the emission maximum at $404 \mathrm{~nm}$. Fluorophore

Table 1. Characterization of samples in respect of sample type (experimental or natural ice or under-ice and initial water), sampling site and salinities. Properties of DOM are described by absorption coefficient at $350 \mathrm{~nm}, \mathrm{a}_{\mathrm{CDOM}, 350}$, spectral slope coefficient for the range $300-$ $400 \mathrm{~nm}$, enrichment factor for maximal fluorescent intensities and average molecular weight. SD: standard deviation; s.i.: significance interval

\begin{tabular}{|c|c|c|c|c|c|c|c|c|c|c|}
\hline \multirow[t]{2}{*}{ Abbreviation } & \multirow[t]{2}{*}{$\begin{array}{l}\text { Sampling } \\
\text { date }\end{array}$} & $\begin{array}{l}\text { Age of } \\
\text { ice }\end{array}$ & \multirow[t]{2}{*}{$\begin{array}{l}\text { Sample } \\
\text { type }\end{array}$} & \multirow[t]{2}{*}{$\begin{array}{l}\text { Sampling } \\
\text { site }\end{array}$} & \multirow[t]{2}{*}{ Salinity } & \multirow{2}{*}{$\begin{array}{c}a_{\mathrm{CDOM}, 350} \\
(\mathrm{SD}) \\
\mathrm{m}^{-1}\end{array}$} & \multirow[t]{2}{*}{$\begin{array}{l}D_{c 350} \\
(\mathrm{SD})\end{array}$} & $\begin{array}{c}\text { Slope }_{300-400} \\
\text { (95\% s.i.) }\end{array}$ & \multirow[t]{2}{*}{$\begin{array}{c}D_{c} \text { of FDOM } \\
\text { C1/C2/C3 }\end{array}$} & \multirow{2}{*}{$\begin{array}{c}R_{\mathrm{t}}^{*}(\mathrm{SD}) \\
\min \end{array}$} \\
\hline & & hours & & & & & & $\mu \mathrm{m}^{-1}$ & & \\
\hline $\exp 08 \mathrm{Wi}$ & 12 Feb 2008 & & $\begin{array}{l}\text { Water before } \\
\text { freezing }\end{array}$ & $\begin{array}{l}\text { Gulf of } \\
\text { Finland }\end{array}$ & 6.4 & $\begin{array}{c}2.3 \\
( \pm 0.02)\end{array}$ & & $21.7( \pm 0.165)$ & & $\begin{array}{c}15.27 \\
( \pm 0.174)\end{array}$ \\
\hline exp08Wui & 26 Feb 2008 & & $\begin{array}{l}\text { Under-ice } \\
\text { water }\end{array}$ & $\begin{array}{l}\text { Gulf of } \\
\text { Finland }\end{array}$ & 7.4 & $\begin{array}{c}2.6 \\
( \pm 0.11)\end{array}$ & $\begin{array}{c}0.01 \\
( \pm 0.018)\end{array}$ & $21.9( \pm 0.21)$ & $0.04 / 0.06 /-0.18$ & $\begin{array}{c}15.01^{*} \\
( \pm 0.013)\end{array}$ \\
\hline exp08ice & 26 Feb 2008 & 144 & Ice (bulk) & $\begin{array}{l}\text { Gulf of } \\
\text { Finland }\end{array}$ & 1.5 & $\begin{array}{c}0.7 \\
( \pm 0.11)\end{array}$ & $\begin{array}{c}0.34 \\
( \pm 0.16)\end{array}$ & $21.5( \pm 0.325)$ & $0.15 / 0.33 / 0.54$ & $\begin{array}{l}15.64^{*} \\
( \pm 0.13)\end{array}$ \\
\hline nat08Wui & 13 Feb 2008 & & $\begin{array}{c}\text { Under-ice } \\
\text { water }\end{array}$ & Tvärminne & 5.8 & 2.9 & & $20.2( \pm 0.15)$ & & 14.81 \\
\hline nat08ice & 13 Feb 2008 & 12 & Ice (bulk) & Tvärminne & 3 & 2.1 & 0.36 & $19.4( \pm 0.16)$ & $0.27 / 0.16 / 0.53$ & 14.86 \\
\hline nat07Wui & 14 Mar 2007 & & $\begin{array}{c}\text { Under-ice } \\
\text { water }\end{array}$ & Tvärminne & 5.6 & 3.7 & & $18.9( \pm 0.08)$ & & \\
\hline exp07Wi & 14 Mar 2007 & & $\begin{array}{l}\text { Water before } \\
\text { freezing }\end{array}$ & Tvärminne & 5.6 & 3.7 & & $18.9( \pm 0.08)$ & & \\
\hline exp07Wui & 14 Mar 2007 & & $\begin{array}{c}\text { Under-ice } \\
\text { water }\end{array}$ & Tvärminne & 6.5 & 4.3 & 0 & $18.8( \pm 0.08)$ & & \\
\hline exp07ice & 14 Mar 2007 & 2 & Ice (bulk) & Tvärminne & 2.1 & 1.9 & 0.34 & $19.5( \pm 0.08)$ & & \\
\hline
\end{tabular}



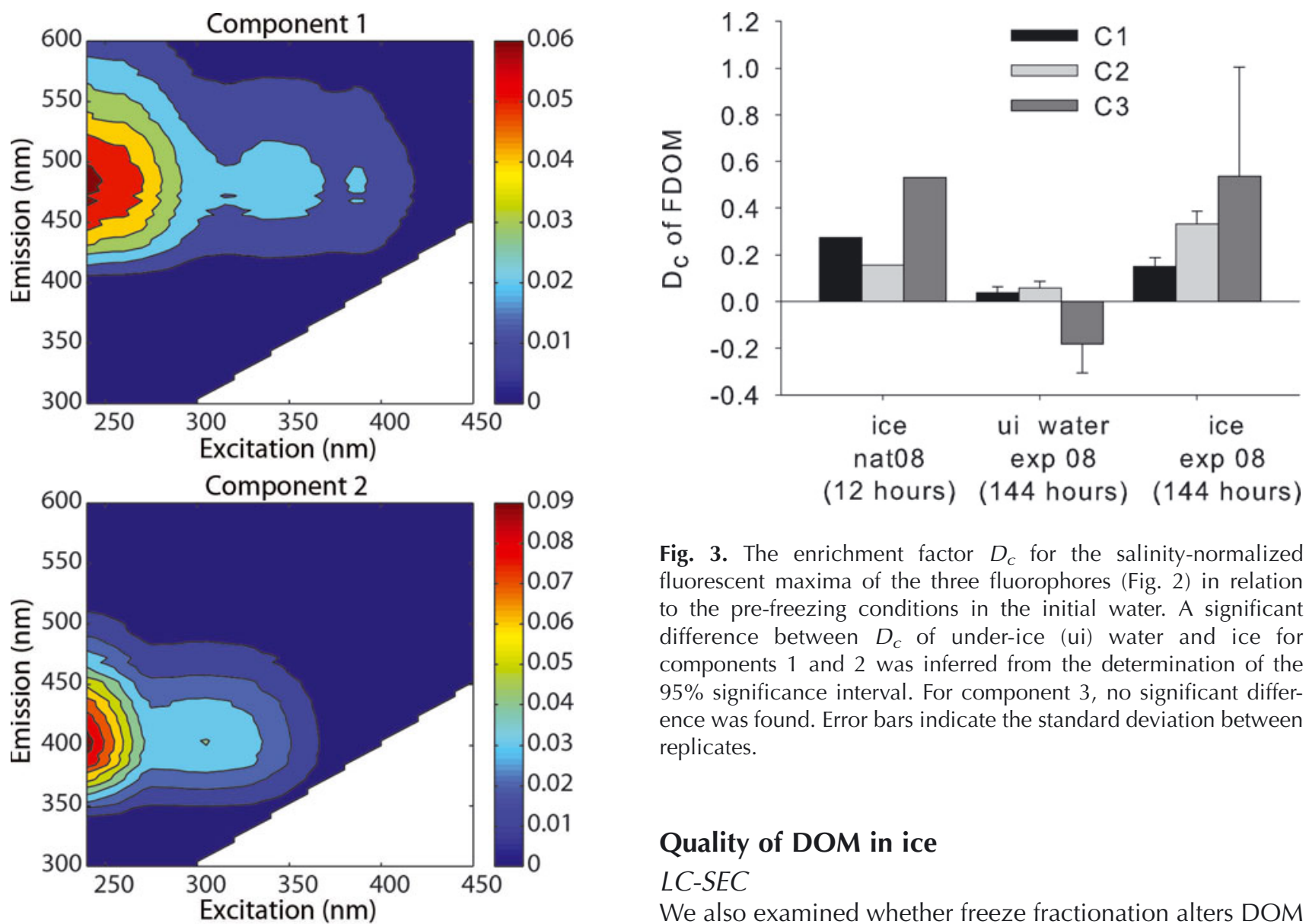

Fig. 3. The enrichment factor $D_{c}$ for the salinity-normalized fluorescent maxima of the three fluorophores (Fig. 2) in relation to the pre-freezing conditions in the initial water. A significant difference between $D_{c}$ of under-ice (ui) water and ice for components 1 and 2 was inferred from the determination of the 95\% significance interval. For component 3, no significant difference was found. Error bars indicate the standard deviation between replicates.

\section{Quality of DOM in ice}

\section{LC-SEC}

We also examined whether freeze fractionation alters DOM in terms of the spectral slope coefficient of CDOM, the composition of fluorophores or the molecular size distribution. The retention times of Baltic Sea DOM were generally larger than those of freshwater fulvic acid (Nordic fulvic acid reference NOFA), but smaller than those of amino acids (tyrosine and phenylalanine) (Fig. 4). The determination of retention time, $R_{\mathrm{t}}$, for DOM by LC-SEC was sensitive to salinity (Fig. 4b). After the dilution of underice water to the salinity of 1 , the absorbance at 15-16 min decreased and shifted towards shorter retention times.

To overcome the effect of salinity on the $R_{\mathrm{t}}$ of DOM, we adjusted the salinity of samples to 1 before examining potential shifts in the molecular size of DOM caused by freezing (Fig. 4c and d). In new natural ice (nat08), the mean $R_{\mathrm{t}}$ of DOM was similar in ice and under-ice water (Fig. $4 \mathrm{e}$ ). The mean $R_{\mathrm{t}}$ of DOM was longer in ice than in under-ice water at a salinity of 1 after 1 week of ice growth (Fig. 4e). This result indicates that the molecular size of DOM was smaller in ice than in under-ice water. tally and naturally grown ice (exp08, nat08). For both datasets, three fluorescent components were identified by PARAFAC modelling. Fluorescence is given in Raman units; note the different scales between the panels.

C3 had excitation maxima at 240 and $280 \mathrm{~nm}$, with the emission maximum at $340 \mathrm{~nm}$. The fluorescence intensities were more than two times higher in water samples than in the corresponding melted ice samples (data not shown).

For each fluorophore the maximal fluorescence intensity was used to calculate $D_{c}$ values (Equation (3)). In both naturally (nat08) and experimentally grown ice (exp08), fluorophores C1 and C2 were significantly enriched in ice, but not in water samples (Fig. 3; Table 1). Fluorophore C3 is not significantly different in ice and water, reasoned from the 95\% significance interval.

\section{Spectral slope}

Because the investigation of the molecular size of DOM indicated that the ageing of ice may change the quality of DOM, we examined the spectral slope coefficient of DOM reported in Table 1 in ice relative to that in water along the age of ice (Fig. 5). Over time, this ratio of slopes decreased from 1.04 in 2 hour old ice to 0.85 in 840 hour old ice.

\section{DOM fluorescence (EEMs)}

In order to investigate changes in the quality of fluorescent DOM during freezing, the fluorophores in young natural ice (nat08) and older artificial ice (exp08) were compared to the corresponding water samples. The composition of fluorophores was similar in ice and water (data not shown). Thus, 


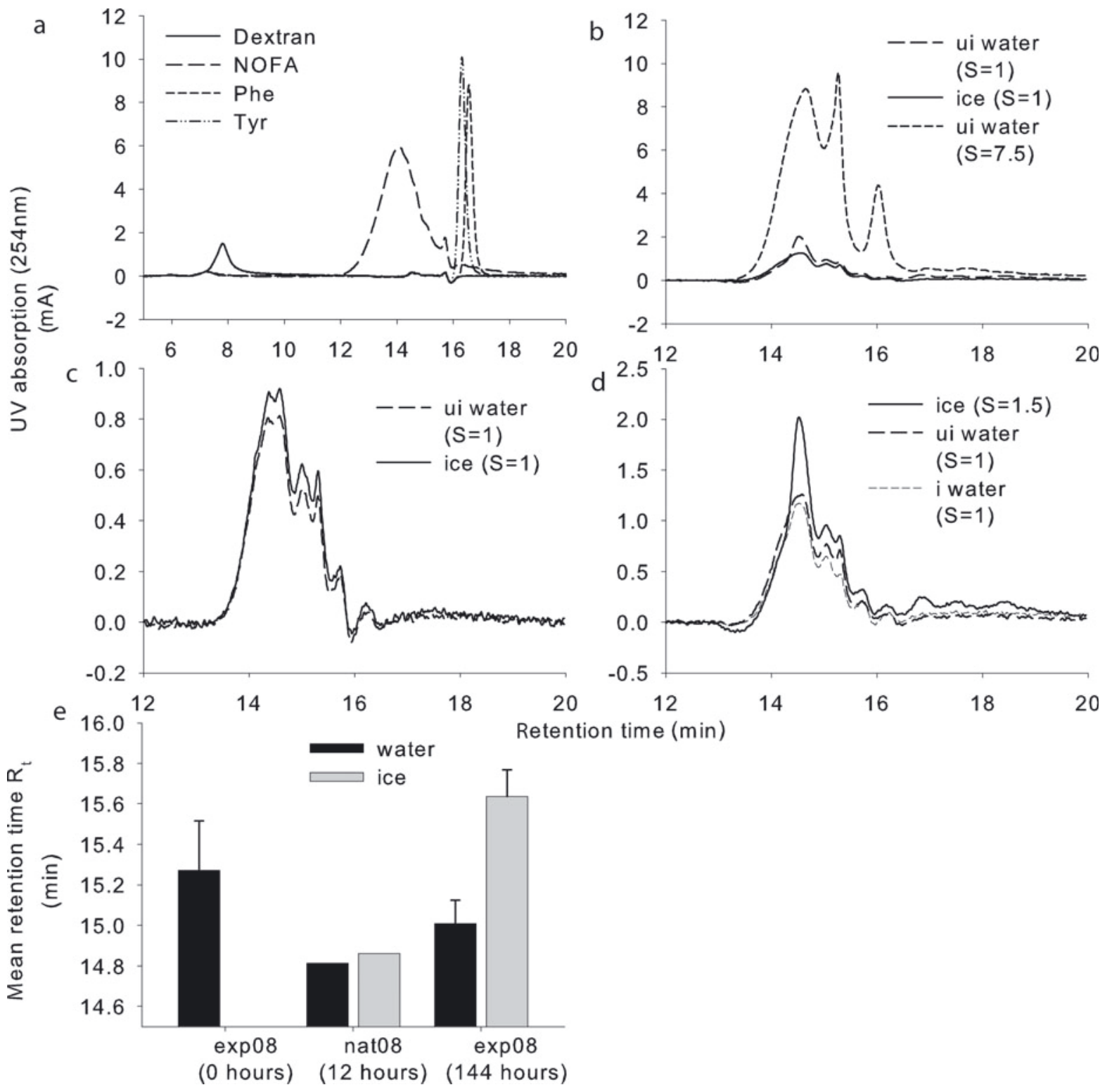

Fig. 4. (a-d) LC-SEC chromatograms of (a) standards; (b) ice and water samples of tank D before and after dilution to salinity of 1; (c, d) water and melted sea ice at a similar ionic strength, directly compared for (c) natural sea ice and (d) experimentally grown ice. Note the different scales. (e) The mean retention time, representing the number average molar mass of DOM in the 12 hour old natural ice (from (c)) and the 144 hour old experimentally grown ice (from (d)).

the freeze fractionation of DOM did not change the composition of fluorophores in our sample set.

\section{DISCUSSION}

\section{Enrichment of DOM relative to salts}

Our study shows that the freezing of Baltic Sea water enriches chromophoric and fluorophoric DOM in ice relative to salts. In our study, the enrichment of CDOM and FDOM in sea ice is similar. This similarity indicates that the observed enrichment of C/FDOM relative to salinity holds also for the bulk DOM as has been found previously for DOC in marine water and brackish waters (Giannelli and others, 2001; Granskog and others, 2004). When we calculated enrichment factors for CDOM and FDOM according to Equation (3) from the original data presented by Belzile and others (2002) and Stedmon and others (2007a), the $D_{C}$ values were also positive, indicating enrichment in the ice of the Baltic Sea and the saline inland waters examined. For freshwater samples studied by Belzile and others (2002), however, $D_{c}$ values are negative, i.e. CDOM is depleted relative to salinity in freshwater lakes.

The salinity-dependent enrichment of DOM into ice can be explained by the structural differences between fresh and saline water ice. Malo and Baker (1968) and Granskog and others (2004) define the minimal salinity of 0.6 for sea-icelike features such as the formation of liquid inclusions. At salinities more than 0.6, the lamellar (instead of freshwaterplanar) ice-water interface allows impurities to be retained in the ice (Eicken, 2003). Despite the lower porosity in the brackish water ice, the enrichment of DOM into the Baltic Sea ice proceeds as in the oceanic waters with salinities of 33 (Giannelli and others, 2001; Kawamura and others, 2001).

Our study shows that enrichment of DOM takes place already during the first hours of ice growth. This is too short a time for sea-ice biota to cause any detectable degradation or production of CDOM, at least under the conditions of our 
study (Vähätalo and Wetzel, 2004). The instant nature of DOM enrichment indicates that physicochemical processes selectively drain out relatively more salts than DOM, which is retained in the brine channels and inclusions to a larger extent than major inorganic ions. The extent of brine rejection depends on the growth rate of ice being highest at the lowest growth of ice in high freezing temperatures (Weeks and Ackley, 1986). The ice growth rate controls the extent of brine rejection (Weeks and Ackley, 1986), being lower at higher growth rates, i.e. lower air temperatures. In this study, the air temperatures range from $-5^{\circ} \mathrm{C}$ to $-20^{\circ} \mathrm{C}$ without any apparent effect on the enrichment of DOM. Altogether our study suggests that an enrichment of DOM is a robust abiotic process taking place immediately during initial ice formation.

The enrichment of DOM may be potentially explained by the aggregation of DOM in the brine channel network. When ice forms from natural sea water containing organic matter and planktonic organisms, a brine channel network forms as salts are excluded from the ice crystals. During this process, highly saline brine is also enriched in organic matter, which can form aggregates. Within the brine channels, increased concentrations of DOM and salts, as well as laminar and turbulent shear forces, can promote the aggregation of DOM as described earlier for transparent exopolymer particles, extracellular polymeric substances or marine biopolymer networks in sea water (Passow, 2002; Meiners and others, 2003; Verdugo and others, 2004; Verdugo, 2007; Ding and others, 2008). If these aggregates of DOM form during the first hours on the surface of brine channels and air inclusions, they can selectively bind more DOM by hydrogen and ionic bonds, the latter found, for example, in cationic complexes (Zhou and others, 1998). The selective binding of DOM into aggregates might explain the faster exclusion of salts compared to DOM and the observed enrichment of DOM already in new sea ice.

\section{Qualitative changes in DOM during freezing}

\section{FDOM and spectral slope}

Our study indicates that the excitation and emission maxima of DOM fluorophores remain the same in sea ice as in the original sea water. Similarly to our findings, any effects of freezing on DOM fluorescence were not observed by Patsayeva and others (2004).

Our spectral slopes are in the range $\left(16-21.9 \mu \mathrm{m}^{-1}\right)$ reported earlier for CDOM in the Baltic Sea (Ferrari and Dowell, 1998; Kowalczuk and others, 2006; Stedmon and others, 2007a; Uusikivi and others, 2010). In our study, the spectral slopes of CDOM in newly formed ice are similar to that of water. This observation suggests that the freezing process does not change the spectral slope of CDOM. The spectral slope is lower in our 5 week old natural ice than in sea water, in agreement with several earlier observations in natural sea ice (Belzile and others, 2000; Ehn and others, 2004; Stedmon and others, 2007a; Uusikivi and others, 2010). Therefore, our results together with the earlier studies suggest that the freezing process does not change the spectral slope, but the processes taking place in the natural ice after freezing tend to decrease the spectral slope of CDOM.

The autochthonous production of DOM in sea ice can potentially decrease the spectral slope in older natural ice. For example, sea-ice algae produce mycosporine-like UVprotecting pigments, which contribute to the absorption of UV radiation by ice (Uusikivi and others, 2010). These

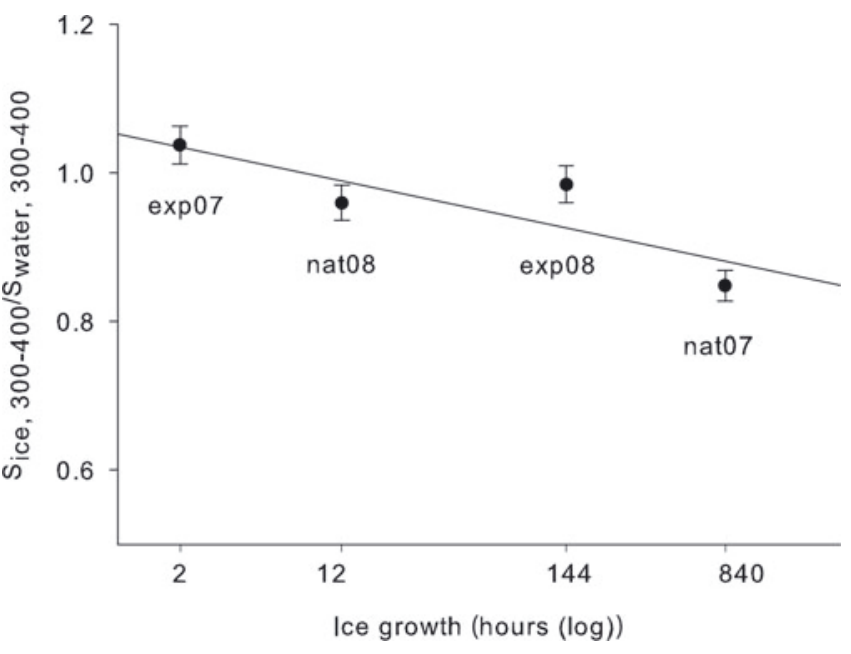

Fig. 5. The ratio between the spectral slope (300-400 nm) of ice and the under-ice water plotted over the time of ice growth at a logarithmic scale (linear regression, $R^{2}=0.85$ ). The median value of all replicates of exp08 is used. Error bars are calculated from the mean sum of the coefficient of variation of the spectral slope of ice and water of each tank of exp08. The resulting mean error of the ratio $(2.5 \%)$ was applied to the other datasets.

pigments are water-soluble, can potentially leach into the dissolved phase and cause decrease in the spectral slope of CDOM (Belzile and others, 2000; Uusikivi and others, 2010).

\section{LC-SEC}

When interpreting the molecular size distribution of DOM in this study, it should be kept in mind that our LC-SEC used a UV detection, which fails to detect weakly absorbing DOM such as carbohydrates (e.g. Dittmar and Kattner, 2003). Thus, our results for the molecular size distribution of DOM concern the chromophoric fraction of DOM rather than bulk DOC. Our finding that an increasing ionic strength apparently decreases the molecular size distribution of DOM assessed by LC-SEC agrees with a number of previous studies (Her and others, 2002; Dittmar and Kattner, 2003; Amy and Her, 2004). Our LC-SEC analyses at the constant salinity of 1 indicate that the freezing as such does not change the molecular size distribution of DOM immediately, but the processes in ice can later decrease it.

One potential factor for the decrease in the molecular size distribution of DOM is the freezing damage of cells followed by leaching and microbial processes. Freezing can damage cells, plasma membranes and certain molecular structures (Roos and others, 1999). In particular, slow freezing is harmful to organic material, and repeated freezing and thawing cycles can hasten the degradation process. The natural circumstances in sea ice are characterized by exactly those slow freezing conditions, rapidly changing temperatures and extreme ionic strength which additionally affect the impact of freezing on organic matter (Giesy and Briese, 1978; Roos and others, 1999). Freezing can also break down proteins of large molecular size to peptides of low molecular weight and release carotenoids, vitamins, sterols and phospholipids into dissolved forms (Uemura and Yoshida, 1986; Puupponen-Pimiä and others, 2003). In fish meat, freezing in combination with inorganic salts hydrolyzes and auto-oxidizes lipids (Sikorski and Kolakowska, 1990). Thus, there is a possibility that the physical freezing process itself breaks down the polymers of 
organic matter to low-molecular-weight molecules and contributes to the observed change in molecular size distribution of DOM in ice in this study. As we observed the production of DOM of low molecular size only after 6 days, microbial processing of freeze-fractionation products needs to be considered: transparent products of cell breakage were potentially transformed by microorganisms into chromophoric DOM within 1 week to be detected by UV absorption applied in this study.

The formation of DOM aggregates, which can explain the instant enrichment of DOM relative to salts, should also change the molecular size distribution of DOM. However, our LC-SEC results show that molecular size distribution of DOM is similar in water and in ice that is a few hours old. If the high concentrations of DOM and salts are the primary forces causing the aggregation of DOM within brine channels, the aggregates of DOM can be expected to break apart at the low concentration of DOM and salts in the melted ice. It is, however, possible that along with the ageing of ice, the aggregates of humic DOM became sufficiently large and stable to be removed by $0.2 \mu \mathrm{m}$ filtration carried out immediately after melting of ice and prior LC-SEC measurements (Giesy and Briese, 1978). Small molecules might instead be bound by cationic complex formation and hydrogen bonding, which will break easily during melting of the sample. The difference in binding stability between small and large molecular sizes can therefore increase the fraction of small molecules in the filtered sample.

Our study shows clearly that the initial freezing results in the enrichment of DOM relative to salts in sea ice. After being trapped in sea ice, DOM is altered by numerous processes such as melting and refreezing, photodegradation, biological degradation and changes in the brine channel network (Niedrauer and Martin, 1979). Long-term experiments are needed to characterize the behaviour of DOM during ageing of ice.

\section{ACKNOWLEDGEMENTS}

We thank the Sea Ice Ecology group for carrying out the experiments with us. C.A. Stedmon introduced us to the PARAFAC modeling. The LC-SEC instruments were provided by the Faculty of Pharmacy of the University of Helsinki. This study was funded by the Walter and Andrée de Nottbeck Foundation and the Academy of Finland. We also thank two anonymous referees for their constructive comments and suggestions

\section{REFERENCES}

Allpike, B.P., A. Heitz, C.A. Joll and R.I. Kagi. 2005. Size exclusion chromatography to characterize DOC removal in drinking water treatment. Environ. Sci. Technol., 39(7), 2334-2342.

Amon, R.M.W. and R. Benner. 1996. Bacterial utilization of different size classes of dissolved organic matter. Limnol. Oceanogr., 41(1), 41-51.

Amy, G. and N. Her. 2004. Size exclusion chromatography (SEC) with multiple detectors: a powerful tool in treatment process selection and performance monitoring. Water Sci. Tech.: Water Supply, 4(4), 19-24.

Belzile, C., S.C. Johannessen, M. Gosselin, S. Demers and W.L. Miller. 2000. Ultraviolet attenuation by dissolved and particulate constituents of first-year ice during late spring in an Arctic polynya. Limnol. Oceanogr., 45(6), 1265-1273.
Belzile, C., J.A.E. Gibson and W.F. Vincent. 2002. Colored dissolved organic matter and dissolved organic carbon exclusion from lake ice: implications for irradiance transmission and carbon cycling. Limnol. Oceanogr., 47(5), 1283-1293.

Benner, R., J.D. Pakulski, M. McCarthy, J.I. Hedges and P.G. Hatcher. 1992. Bulk chemical characteristics of dissolved organic matter in the ocean. Science, 255(5051), 1561-1564.

Ding, Y.-X., W.-C. Chin, A. Rodriguez, C.-C. Hung, P.H. Santschi and P. Verdugo. 2008. Amphiphilic exopolymers from Sagittula stellata induce DOM self-assembly and formation of marine microgels. Mar. Chem., 112(1-2), 11-19.

Dittmar, T. and G. Kattner. 2003. Recalcitrant dissolved organic matter in the ocean: major contribution of small amphiphilics. Mar. Chem., 82(1-2), 115-123.

Ehn, J., M.A. Granskog, A. Reinart and A. Erm. 2004. Optical properties of melting landfast sea ice and underlying seawater in Santala Bay, Gulf of Finland. J. Geophys. Res., 109(C9), C09003. (10.1029/2003JC002042.)

Eicken, H. 2003. From the microscopic, to the macroscopic, to the regional scale: growth, microstructure and properties of sea ice. In Thomas, D.N. and G.S. Dieckmann, eds. Sea ice: an introduction to its physics, chemistry, biology and geology. Oxford, Blackwell Publishing, 22-81.

Ferrari, G.M. and M.D. Dowell. 1998. CDOM absorption characteristics with relation to fluorescence and salinity in coastal areas of the southern Baltic Sea. Estuar. Coast. Shelf Sci., 47(1), 91-105.

Giannelli, V., D.N. Thomas, C. Haas, G. Kattner, H. Kennedy and G.S. Dieckmann. 2001. Behaviour of dissolved organic matter and inorganic nutrients during experimental sea-ice formation. Ann. Glaciol., 33, 317-321.

Giesy, J.P. and L.A. Briese. 1978. Particulate formation due to freezing humic waters. Water Resour. Res., 14(3), 542-544.

Granskog, M.A., M. Leppäranta, T. Kawamura, J. Ehn and K. Shirasawa. 2004. Seasonal development of the properties and composition of landfast sea ice in the Gulf of Finland, the Baltic Sea. J. Geophys. Res., 109(C2), C02020. (10.1029/ 2003JC001874.)

Granskog, M.A., H. Kaartokallio, D.N. Thomas and H. Kuosa. 2005. Influence of freshwater inflow on the inorganic nutrient and dissolved organic matter within coastal sea ice and underlying waters in the Gulf of Finland (Baltic Sea). Estuar. Coast. Shelf Sci., 65(1-2), 109-122.

Her, N., G. Amy, D. Foss, J. Cho, Y. Yoon and P. Kosenka. 2002. Optimization of method for detecting and characterizing NOM by HPLC-size exclusion chromatography with UV and on-line DOC detection. Environ. Sci. Technol., 36(5), 1069-1076.

Hongve, D., J. Baann, G. Becher and S. Lømo. 1996. Characterization of humic substances by means of high-performance size exclusion chromatograph. Environ. Int., 22(5), 489-494.

Kawamura, T. and 9 others. 2001. Time-series observations of the structure and properties of brackish ice in the Gulf of Finland. Ann. Glaciol., 33, 1-4.

Kowalczuk, P., C.A. Stedmon and S. Markager. 2006. Modeling absorption by CDOM in the Baltic Sea from season, salinity and chlorophyll. Mar. Chem., 101(1-2), 1-11.

Lakowicz, J.R. 1999. Principles of fluorescence spectroscopy. Second edition. New York, Springer.

Malo, B.A. and R.A. Baker. 1968. Cationic concentration by freezing. In Gould, R.F., ed. Trace inorganics in water. Washington, DC, American Chemical Society, 149-163. (Advances in Chemistry 73.)

Meiners, K., J. Fehling, M.A. Granskog and M. Spindler. 2002. Abundance, biomass and composition of biota in Baltic sea ice and underlying water (March 2000). Polar Biol., 25(10), $761-770$

Meiners, K., R. Gradinger, J. Fehling, G. Civitarese and M. Spindler. 2003. Vertical distribution of exopolymer particles in sea ice of the Fram Strait (Arctic) during autumn. Mar. Ecol. Progr. Ser., 248, 1-13. 
Mobed, J.J., S.L. Hemmingsen, J.L. Autry and L.B. McGown. 1996. Fluorescence characterization of IHSS humic substances: total luminescence spectra with absorbance correction. Environ. Sci. Technol., 30(10), 3061-3065.

Niedrauer, T.M. and S. Martin. 1979. An experimental study of brine drainage and convection in young sea ice. J. Geophys. Res., 84(C3), 1176-1186.

Ohno, T. 2002. Fluorescence inner-filtering correction for determining the humification index of dissolved organic matter. Environ. Sci. Technol., 36(4), 742-746.

Passow, U. 2002. Transparent exopolymer particles (TEP) in aquatic environments. Progr. Oceanogr., 55(3-4), 287-333.

Patsayeva, S., R. Reuter and D.N. Thomas. 2004. Fluorescence of dissolved organic matter in seawater at low temperatures and during ice formation. EARSeL eProc., 3(2), 227-238.

Puupponen-Pimiä, R. and 8 others. 2003. Blanching and long-term freezing affect various bioactive compounds of vegetables in different ways. J. Sci. Food Agric., 83(14), 1389-1402.

Roos, Y.H., R.B. Leslie and P.J. Lillford, eds. 1999. Water management in the design and distribution of quality foods. Lancaster, PA, Technomic.

Sikorski, Z.E. and A. Kolakowska. 1990. Freezing of marine food. In Sikorski, Z.E., ed. Seafood: resources, nutritional composition and preservation. Boca Raton, FL, CRC Press.

Stedmon, C.A. and R. Bro. 2008. Characterizing dissolved organic matter fluorescence with parallel factor analysis: a tutorial. Limnol. Oceanogr. Meth., 6, 572-579.

Stedmon, C.A. and S. Markager. 2003. Behaviour of the optical properties of coloured dissolved organic matter under conservative mixing. Estuar. Coast. Shelf Sci., 57(5-6), 973-979.

Stedmon, C.A., S. Markager and H. Kaas. 2000. Optical properties and signatures of chromophoric dissolved organic matter (CDOM) in Danish coastal waters. Estuar. Coast. Shelf Sci., 51(2), 267-278.

Stedmon, C.A., S. Markager and R. Bro. 2003. Tracing dissolved organic matter in aquatic environments using a new approach to fluorescence spectroscopy. Mar. Chem., 82(3-4), 239-254.

Stedmon, C.A., D.N. Thomas, M. Granskog, H. Kaartokallio, S. Papadimitriou and H. Kuosa. 2007a. Characteristics of dissolved organic matter in Baltic coastal sea ice: allochthonous or autochthonous origins? Environ. Sci. Technol., 41(21), 7273-7279.

Stedmon, C.A., S. Markager, L. Tranvik, L. Kronberg, T. Slätis and W. Martinsen. 2007b. Photochemical production of ammonium and transformation of dissolved organic matter in the Baltic Sea. Mar. Chem., 104(3-4), 227-240.

Thomas, D.N., R.J. Lara, H. Eicken, G. Kattner and A. Skoog. 1995. Dissolved organic matter in Arctic multi-year sea ice during winter: major components and relationship to ice characteristics. Polar Biol., 15(7), 477-483.

Thomas, D.N. and 6 others. 2001. Dissolved organic matter in Antarctic sea ice. Ann. Glaciol., 33, 297-303.

Thomas, D.N. and 8 others. 2008. The biology of polar regions. Oxford, etc., Oxford University Press.

Twardowski, M.S., E. Boss, J.M. Sullivan and P.L. Donaghay. 2004. Modeling the spectral shape of absorption by chromophoric dissolved organic matter. Mar. Chem., 89(1-4), 69-88.

Uemura, M. and S. Yoshida. 1986. Studies on freezing injury in plant cells: II. protein and lipid changes in the plasma membranes of Jerusalem artichoke tubers during a lethal freezing in vivo. Plant Physiol., 80(1), 187-195.

Uusikivi, J., A.V. Vähätalo, M.A. Granskog and R. Sommaruga. 2010. Contribution of mycosporine-like amino acids and colored dissolved and particulate matter to sea ice optical properties and ultraviolet attenuation. Limnol. Oceanogr., 55(2), 703-713.

Vähätalo, A.V. 2009. Light, photolytic reactivity and chemical product. In Likens, G., ed. Encyclopedia of inland waters. Amsterdam, Elsevier, 761-773.

Vähätalo, A.V. and R.G. Wetzel. 2004. Photochemical and microbial decomposition of chromophoric dissolved organic matter during long (months-years) exposures. Mar. Chem., 89(1-4), 313-326.

Verdugo, P. 2007. Dynamics of marine biopolymer networks. Polym. Bull., 58(1), 139-143.

Verdugo, P., A.L. Alldredge, F. Azam, D.L. Kirchman, U. Passow and P.H. Santschi. 2004. The oceanic gel phase: a bridge in the DOM-POM continuum. Mar. Chem., 92(1-4), 67-85.

Vihma, T. and J. Haapala. 2009. Geophysics of sea ice in the Baltic Sea: a review. Progr. Oceanogr., 80(3-4), 129-148.

Weeks, W.F. and S.F. Ackley. 1982. The growth, structure, and properties of sea ice. CRREL Monogr. 82-1.

Weeks, W.F. and S.F. Ackley. 1986. The growth, structure, and properties of sea ice. In Untersteiner, N., ed. Geophysics of sea ice. London, etc., Plenum Press, 9-164. (NATO ASI Series B: Physics 146.)

Zhou, J., K. Mopper and U. Passow. 1998. The role of surface-active carbohydrates in the formation of transparent exopolymer particles by bubble adsorption of seawater. Limnol. Oceanogr., 43(8), 1860-1871. 